Proceeding

\title{
Study of the effect of solvent and different Lewis acids in one pot multicomponent microwave assisted reaction for the chemoselective generation of 1.4-thiazepan-3-ones and 4-thiazolidinones. ${ }^{+}$
}

\author{
Quiroga A. A. ${ }^{1}$, Costilla I. O. ${ }^{2}$, Lorenzo F. J. ${ }^{1}$, Calmels J. J. ${ }^{1}$, Villafain D. ${ }^{1}$, Mandolesi S. D. ${ }^{1}$, \\ D'Accorso N. B, ${ }^{3}$ Ocampo R. A.* ${ }^{* 1}$ \\ ${ }^{1}$ Departamento de Química, Universidad Nacional del Sur (UNS), Avenida Alem 1253, 8000 Bahía Blanca, Argentina. \\ E-mail:sdmando@criba.edu.ar. \\ ${ }^{2}$ Instituto de Física del Sur (IFISUR-CONICET), Universidad Nacional del Sur, Avenida Alem 1253, 8000 Bahía Blanca, \\ Argentina. E-mail: Ignacio.costilla@uns.edu.ar. \\ ${ }^{3}$ Centro de Investigaciones en Hidratos de Carbono (CIHIDECAR-CONICET), Departamento de Química Orgánica, \\ FCEN, UBA, Intendente Guiraldes 2160, Ciudad Universitaria, C1428EGA Buenos Aires, Argentina. E-mail: \\ norma@qo.fcen.uba.ar. \\ * Correspondence: rocampo@uns.edu.ar; Tel.: +54-291-402-3839 \\ † Presented at XXI ECSOC, 1-30 November 2017. \\ Academic Editor: name \\ Received: date; Accepted: date; Published: date
}

Abstract: With the aim of exploring the best reaction conditions for the diastereoselective synthesis of the 1,4-thiazepan-3-ones (4) and 4-thiazolidinones (5), we have studied the effect on solvent variation and the aggregation of $\mathrm{AlCl}_{3}$ and different zeolites as Lewis acid catalysts to the three-component microwave assisted reaction between 2,3:4,5-di-O-isopropylidene- $\beta$-Darabino-hexos-2-ulo-2,6-pyranose (1), benzotiazole (3) and thioglycolic acid (2). Based on the results of previous studies of our group, we discuss here two microwave assisted methods: multicomponent reaction in the presence of the catalysts (Method A) and sequential reaction with generation of the corresponding intermediates and subsequent addition of the catalysts coordinated to thioglycolic acid (Method B).

Keywords: 4-thiazolidinones; 1,4-thiazepan-3-ones; zeolites as Lewis catalysts; microwave.

\section{Introduction}

The synthetic field of Organic Chemistry plays an important role in the study of new substances which present biological and pharmacological activities that can be used for the development of therapeutic agents as the mainstay for the progress of medicinal chemistry. A wide variety of heterocycles are present as the main structural component in different categories of drugs [1]. This facts reflect the contribution of the heterocycle core in a great number of biochemical processes. Between them, functionalized 1,4-thioazepan-3-ones [2] and thiazolidinones [3] represent an important group that has been tested as potential active compounds in pharmaceutical studies 
and because of this, they are important "building blocks" in organic synthesis for the design of new versatile molecules with biologic activity.

Thus, the inclusion of a carbohydrate moiety in these heterocyclic molecules is a strategy that can be used for the increasing of the solubility of the drug and/or diminish its toxicity and as a renewable resource with high functionality and a large number of asymmetric sites that allows, through the adequate planification of the synthetic route, the preparation of enantiomeric pure compounds.

Based on the previous studies of our research group, we could established that the tricomponent microwave assisted reaction between 2,3:4,5-di-O-isopropylidene- $\beta$-D-arabino-hexos2-ulo-2,6-pyranose (1), mercaptoacetic acid (2) and various heteroaromatic amines (3), without solvent (Method A), proved to be a simple eco-friendly method because of the atoms economy, reaction time, high yields and low cost economic starting products for the synthesis of the corresponding 4-thiazolidinones (5) as the only products and as diastereomeric mixtures [4,5]. On the other side, when stoichiometric amounts of the boronic ester A (dimethyl-(4S,5S)-2-phenyl1,3,2-dioxaborolane-4,5-dicarboxylate) was added together with the reactants 1, 2 and 3, not only selective formation of diastereomers from 1,4-thiazepan-3-one (4) was observed but also an increase in the proportion of one of them (Figure 1) [6,7].

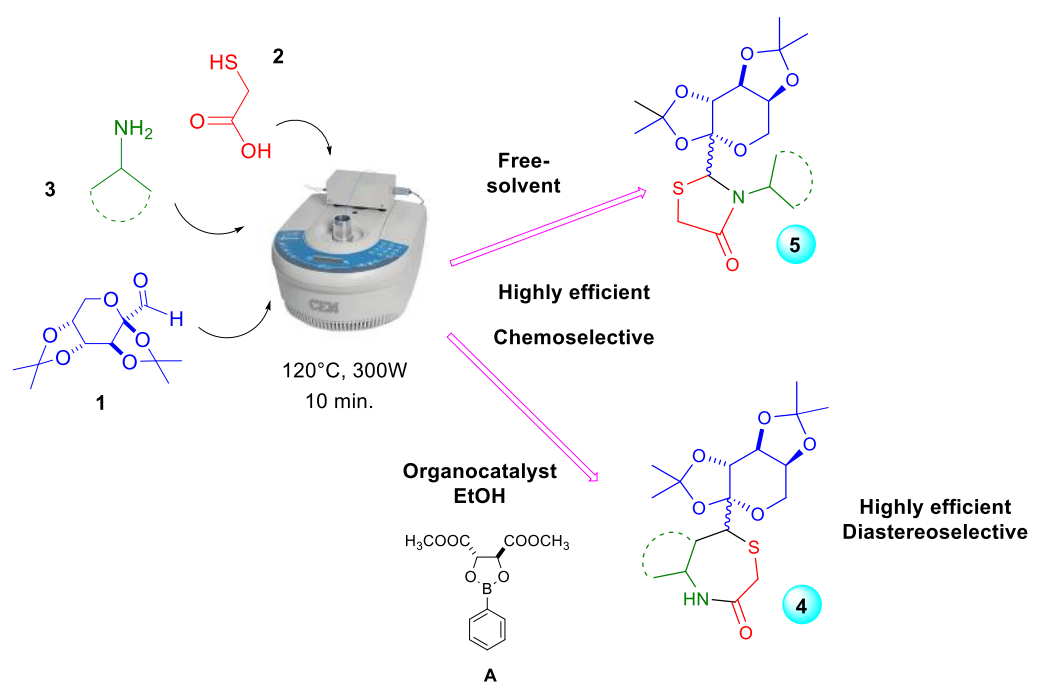

Figure 1. Microwave assisted three component reactions (Method A).

We have also observed that the use of the same organoboron catalyst in the sequential reaction (Method B) generates the corresponding 4-thiazolidinones (5) as the only reaction products. In addition, catalysis produces diastereoselectivity between type $\mathbf{5}$ products, contrary to what is observed in the absence of catalyst. The possible reaction mechanism in shown in Figure 2. The addition of thioglycolic acid coordinated to bulky organoboron catalyst $\mathbf{A}$ on the intermediate imine preformed (II) prevents the attack on one of the faces of the intermediate and high diastereoselectivity was imparted to the reaction. 


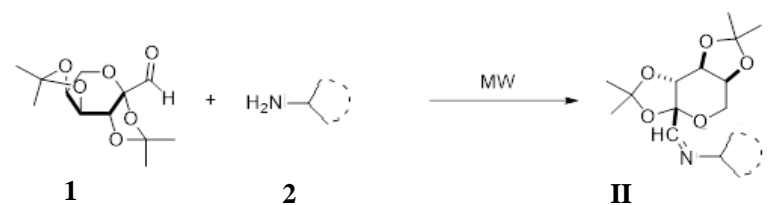

1

2

II

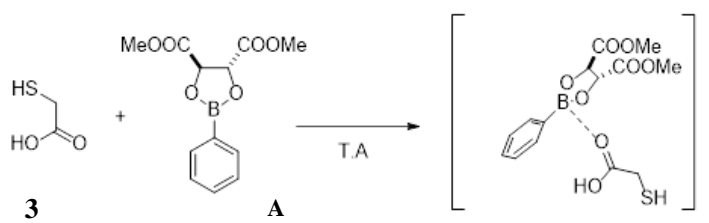

3

A

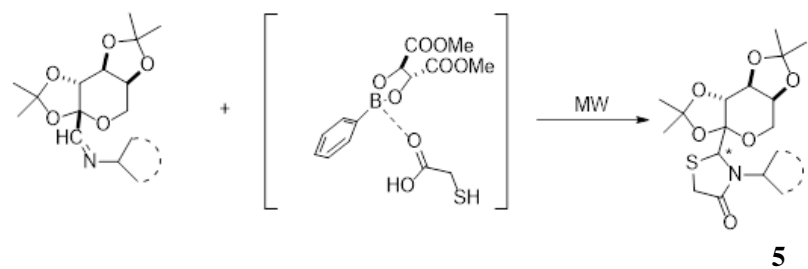

Figure 2. Sequential microwave assisted reaction (Method B). First step: generation of the intermediate (II). Second step: addition of the thioglicolic acid coordinated to the organoboroncatalyst.

\section{Results and Discussion}

According to previous reported studies, [8] we know that the proposed intermediates I and II generated in the reaction are fundamental for the synthesis of each one of the products (Figure 4). In order to synthetize, in a quimioselective way, the generation of 1,4-thioacepan-3-ones (4) or 4-thiazolidinones (5) we studied the possible factors that could affect the tricomponent reaction using Method A and the diastereoselectivity in the sequential reaction through Method B conditions. We will evaluate which products are obtained monitoring the reactions by CG-MS, taking samples every five minutes.

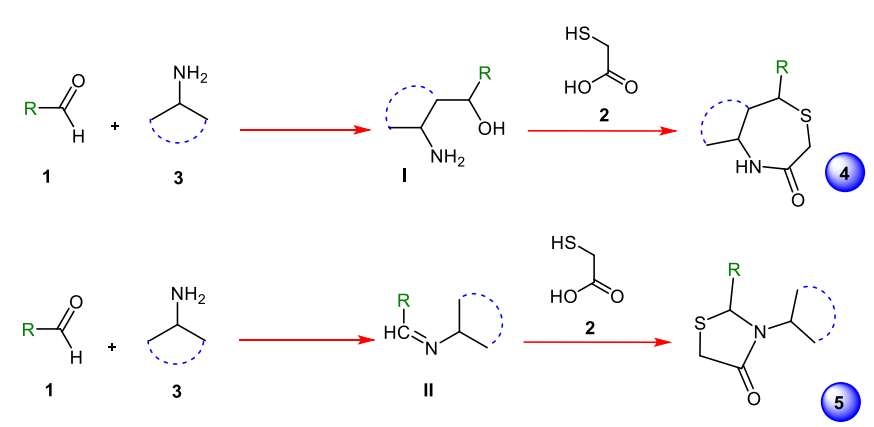

Figure 4. Proposed intermediates I and II and products of the tricomponent assisted microwave reaction.

Then, we will extend the study using $\mathrm{AlCl}_{3}$ and commercial zeolites (Mordenite, Zeolite 13X and Zeolite ZSM-5) as Lewis acid catalysts supported on a mesoporous material. Previously, we performed the corresponding determination of the surface area of the zeolites by the BET method [9] (Table 1) and the Diffuse Reflectance FTIR Sample Techniques (DRIFTS) for the analysis of acid sites through pyridine adsorption (Figure 6) [10]. 
Table 1: Determined BET area for the zeolites used as Lewis acid catalysts.

\begin{tabular}{|c|c|c|c|c|c|}
\hline $\begin{array}{c}\text { Zeolite } \\
\text { (comercial) }\end{array}$ & $\begin{array}{c}\text { Calculated } \\
\text { BET area } \\
{\left[\mathbf{m}^{2} / \mathbf{g}\right]}\end{array}$ & $\begin{array}{c}\text { Cristalinity } \\
\text { X-Ray } \\
\text { difraction }\end{array}$ & Si/Al & $\%$ Na & $\begin{array}{c}\text { BET área } \\
{\left[\mathbf{m}^{2} / \mathbf{g}\right]} \\
\text { (literature) }\end{array}$ \\
\hline $\begin{array}{c}\text { H-mordenite } \\
\text { (Zeolist) CBV 21A }\end{array}$ & 291 & $100 \%^{\mathrm{c}}$ & $10^{\mathrm{b} c}$ & ---- & $\begin{array}{c}500^{\mathrm{c}} \\
346^{\mathrm{d}}\end{array}$ \\
\hline $\begin{array}{c}13 \mathrm{X}, \\
\text { tamix molecular }\end{array}$ & 376 & ---- & 1,5 & ---- & $515^{\mathrm{e}}$ \\
\hline $\begin{array}{c}\text { ZSM-5 } \\
(\text { Zeocat Pentasil) } \\
\text { PZ-2/54 }\end{array}$ & 333 & $99,4 \%^{\mathrm{a}}$ & $20^{\mathrm{a}}$ & $0,43^{\mathrm{a}}$ & $350^{\mathrm{a}}$ \\
\hline
\end{tabular}

aSee reference [11]. ${ }^{\mathrm{b}}$ See reference [12]. ${ }^{\mathrm{c}}$ See reference [13]. ${ }^{\mathrm{d}}$ See reference [14]. ${ }^{\mathrm{e}}$ See reference [15].

The FT-IR spectra registered at room temperature, after pyridine adsorption and purge under $100^{\circ} \mathrm{C}$ for the different zeolites, show important absorption bands around 1450, 1500 and $1600 \mathrm{~cm}^{-1}$, typical for the C-C bonds of the pyridine structure. The coordination between pyridine and the Lewis acid center can be identified by the $1450 \mathrm{~cm}^{-1}$ absorption band while the coordination with the Brönsted acid center is around $1540 \mathrm{~cm}^{-1}$. The absorption band at $1600 \mathrm{~cm}^{-1}$ is generally associated to the pyridine-hydrogen bond. Rosenthal et al. [16] found that the extinction coefficients for Lewis acid-pyridine and Brönsted acid-pyridine were the same, so the relation Brönsted acid / Lewis acid for our zeolites could be calculated. In Figure 5, it can be seen that all the samples showed only Lewis acid activity because the absorption band corresponding to 1540 $\mathrm{cm}^{-1}$ is not observed in the analyzed spectra.

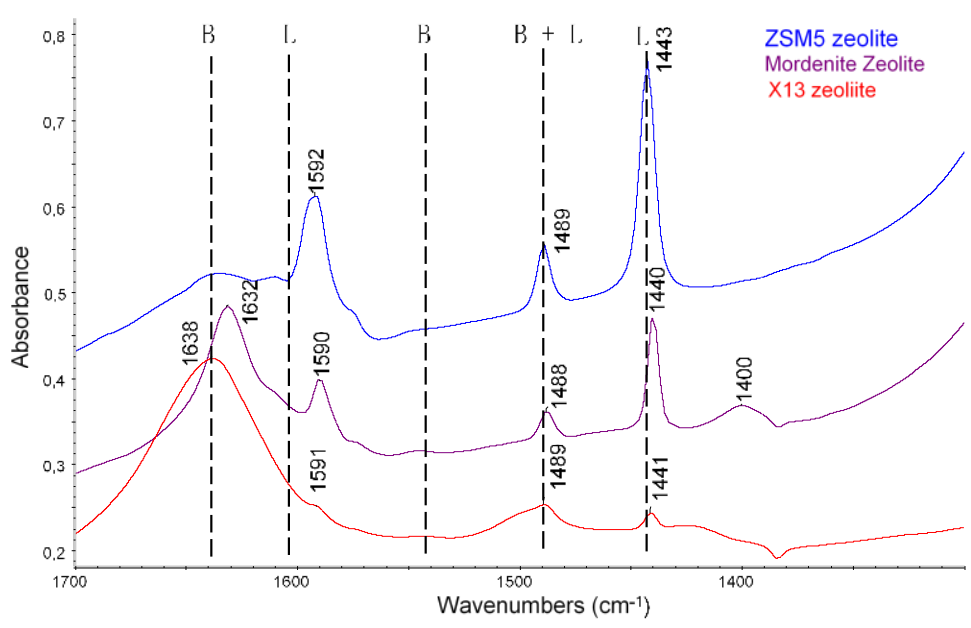

Figure 5. IR spectra of pyridine adsorbed at $20^{\circ} \mathrm{C}$ on the different zeolites pre-treated in $\mathrm{N}_{2}$ flow at $400{ }^{\circ} \mathrm{C}$.

Considering that the pore size of these catalysts increases in the presence of solvents, we started the evaluation of several solvents in the tricomponent reactions assisted by microwave $(300 \mathrm{~W}$, $120^{\circ} \mathrm{C}$, Method A) with the aim of evaluate which solvent gives better yields and no effect in the diastereoselectivity of the reaction. The model starting heterocyclic amine employed was aminobenzothiazole. The results for the generation of products 4 and/or 5 and their corresponding 
proposed intermediates I and II together with the CG-MS spectra are shown in Table 2 and Figure 6 respectively.

Table 2. Solvent effect on the synthesis of compounds 4 and 5 and their corresponding proposed intermediates I and II

\begin{tabular}{cccccc}
\hline \\
Entry
\end{tabular}

Reaction Conditions: One pot microwave-assisted multicomponent reaction of 2,3:4,5-di-Oisopropylidene- $\beta$-D-arabino-hexos-2-ulo-2,6-pyranose $(\mathbf{1} \mathbf{~ m m o l})$ using benzotiazole $(\mathbf{1} \mathbf{~ m m o l})$, thioglycolic acid

$(\mathbf{1} \mathbf{~ m m o l})$ and solvent $(\mathbf{1 ~ m L})$ at $300 \mathrm{~W}$ and $120^{\circ} \mathrm{C}$ during 30 min. ${ }^{a}$ Determined by CG-MS analysis of crude reaction through a standard curve generated from isolated pure product.

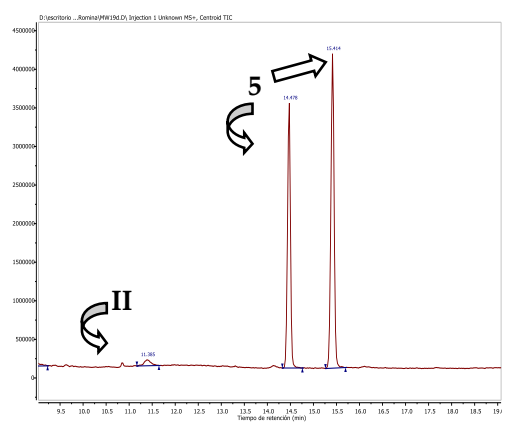

(a)

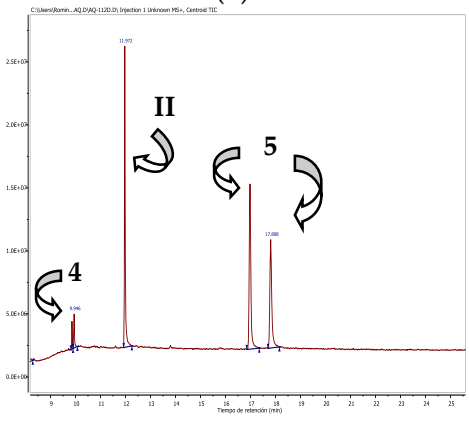

(c)

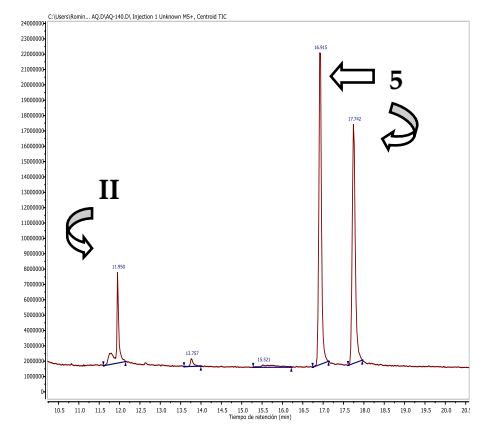

(b)

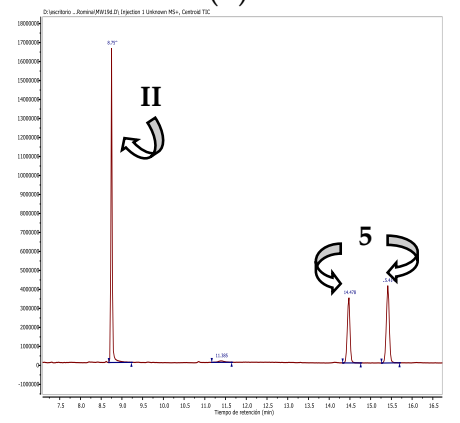

(d)

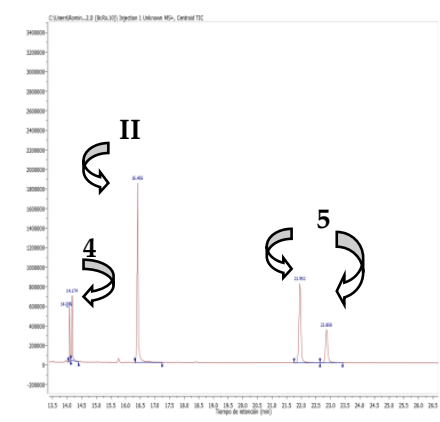

(e)

Figure 6. CG-MS of the crude products of the multicomponent reaction: without solvent (a), in methanol (b); in toluene (c); in ethanol (d); in dichloromethane (e). 
When toluene and dicholoromethane are used as the only solvent reaction (entry 3 and 5 respectively), both type 4 and 5 compounds are obtained in similar diastereomeric mixtures. Intermediate II was detected and remained unreacted after 30 minutes. However, intermediate I was not observed and, because of this, we can assume that its high reactivity promotes that the type 4 corresponding products are rapidly formed, although with low diastereoselectivity.

Taking into account that the results obtained with methanol and ethanol (entry 2 and 4 respectively) as solvent are very similar, this is, only the products with five members cycle (5) were observed as a diastereoisomeric mixture with similar proportions of both stereoisomers, we decided to choose ethanol because it is an eco-friendly-economic solvent which would not exert influence on the diastereoselectivity of the reaction and will allow us to evaluate just the effect of the catalysts.

The monitoring of the progress of the reaction was made by CG-MS. The results obtained using Method $\mathbf{A}$ and $\mathbf{B}$ with $\mathrm{AlCl}_{3}$ and Zeolites as Lewis acids in the reaction of 2,3:4,5-di-O-isopropylidene- $\beta$-D-arabino-hexos-2-ulo-2,6-pyranose, benzotiazole, thioglycolic acid and the catalysts in ethanol at $300 \mathrm{~W}$ and $120^{\circ} \mathrm{C}$ are shown in Table 3.

Table 3. Catalyst effect of different Lewis Acids on the synthesis of compounds 4 and 5 and the intermediate II.

\begin{tabular}{cccc}
\hline \\
Method A
\end{tabular}

a Determined by CG-MS analysis of crude reaction during $30 \mathrm{~min}$ of irradiation through a standard curve generated from isolated pure product.

As can be seen from Table 3, the reaction with $\mathrm{AlCl}_{3}$ as Lewis acid (entry 1) showed no significant results because both type 4 and 5 products are formed under the Method A conditions. Although Method B gave only type 5 products, the diastereomeric relation observed was poor together with a low yield. This is probably because $\mathrm{ALCl}_{3}$ is not capable of inducing in a suitable way the diastereoselectivity of the reaction. In both cases, 9 and $49 \%$ respectively of intermediate II remained unreacted.

When Mordenite is used (entry 2), it can be observed that the results obtained under Method A conditions are very similar to those found when $\mathrm{AlCl}_{3}$ was employed, although only traces of intermediate II was detected at the end of the reaction. However, with Method B, only type 5 
products were generated with good diastereoselectivity (74:26) and 62\% yield. Again, in both cases, 7 and $38 \%$ respectively of intermediate II remained unreacted.

In the case of the utilization of zeolites $13 X$ (entry 3 ) the best results were obtained regarding to the synthesis of type 5 products with Method B, not only because of the high diastereomeric relation (12:88) but in the excellent yield observed (90\%), although $10 \%$ of intermediate II was detected at the end of the reaction. Method A gave a mixture of type 4 and 5 products with good $\mathrm{dr}$ and only traces of the intermediate II was detected.

Finally, entry 4 shows that ZSM-5 gave only type products 4 in quantitative yield in a diastereomeric relation 40:60 under Method A conditions. In the case of the sequential method (Method B), the formation of the type 5 product was observed in a very good diastereoselectivity (79:21) and 70\% of reaction yield. Intermediate II was detected only in the last case (30\%).

From all these results, the zeolite nature proved to be critical. It can be seen that zeolite $13 \mathrm{X}$ is the best catalyst regarding to the diastereoselectivity found in the generation of type 4 and 5 products under Methods A and B respectively and this is probably because this catalyst has the biggest pore size (see Table 1). It is well known that the internal shapes of the zeolites have a great influence in reaction efficiency and that this is directly correlated with pore size.[17] So, the reacting molecules should be in a favorable location to provide a good accessibility to the catalyst acid center in order to favor the attack on one of the faces of the intermediate.

Similar analysis can be done for ZSM-5 and Mordenite. The diastereoselectivity diminishes respectively in the same way that the pore size of these catalysts decrease.

\section{Materials and Methods}

\subsection{General Information:}

Mass spectra were obtained with a GC/MS instrument (HP5-MS capillary column, $30 \mathrm{~m} / 0.25$ $\mathrm{mm} / 0.25 \mathrm{~mm}$ ) equipped with 5972 mass selective detector operating at $70 \mathrm{eV}$ (EI). Infrared spectra were recorded with a Nicolet Nexus 470 FT spectrometer. Microwave reactions were performed with a microwave oven (CEM Discover $\left.{ }^{\circledR}\right)$ with a continuous focused microwave power delivery system in a pressure glass vessel $(10 \mathrm{~mL})$ sealed with a septum under magnetic stirring. The reaction mixture temperature was monitored using a calibrated infrared temperature control under the reaction vessel, and control of the pressure was performed with a pressure sensor connected to the septum of the vessel.

\subsection{General reaction conditions:}

Method A: One pot microwave-assisted multicomponent reaction: A mixture of 2,3:4,5-di-O-isopropylidene- $\beta$-D-arabino-hexos-2-ulo-2,6-pyranose ( $0.242 \mathrm{~g}, 1 \mathrm{mmol})$, benzothiazole $(0.15 \mathrm{~g}, \mathrm{mmol})$, thioglycolic acid $(0.07 \mathrm{~mL}, 1 \mathrm{mmol})$ and the corresponding solvent used in each case $(1 \mathrm{~mL})$ were heated in the microwave apparatus at $300 \mathrm{~W}$ and $120^{\circ} \mathrm{C}$ for 30 minutes. In cases where zeolites were used, they were filtered from the respective crude reaction using $2 \mathrm{~mL}$ of ethanol as washing solvent. The analysis of the ratio of intermediate and products generated during the course of the reaction were monitored taking aliquots for consecutive periods of 5 minutes for GC-MS analysis.

Method B: Sequential reaction: 2,3:4,5-di-O-isopropylidene- $\beta$-D-arabino-hexos-2-ulo-2,6pyranose $(0.242 \mathrm{~g}, 1 \mathrm{mmol})$, benzothiazole $(0.15 \mathrm{~g}, \mathrm{mmol})$ and ethanol $(1 \mathrm{~mL})$ were irradiated at 300 $\mathrm{W}$ and $120^{\circ} \mathrm{C}$ during $30 \mathrm{~min}$. On the other hand, thioglycolic acid $(0.07 \mathrm{~mL}, 1 \mathrm{mmol})$ is kept under stirring at room temperature in the presence of the corresponding catalyst $(20 \mathrm{mg})$ for 10 minutes. 
Then, thioglycolic acid coordinated to the catalyst is added to the preformed imine and irradiated under the same conditions 30 minutes, monitoring aliquots taken every 5 min by GC-MS. In cases where zeolites were used, they were filtered from the respective crude reaction using $2 \mathrm{~mL}$ of ethanol as washing solvent.

\subsection{BET Area Analysis:}

The surface area of the commercial zeolites (mordenite, 13X zeolite and ZSM-5 zeolite) was determined by the technique developed by Brunauer, Emmet, and Teller (BET) [9]. The measured was performed by nitrogen adsorption isotherms at $77 \mathrm{~K}$ in a Quantachrome Nova 1200e. Samples before each analysis were degassed at $200{ }^{\circ} \mathrm{C}$ under vacuum. To obtain the adsorption isotherm, the sample was encapsulated and increasing pressure of $\mathrm{N}_{2}$ was applied. The results obtained by linear regression equation of BET determined the specific surface area in $\mathrm{m}^{2} / \mathrm{g}$.

\subsection{Isotherms of Pyridine Adsorption:}

Diffuse spectral reflectance infrared (DRIFTS) spectra were recorded on a Nicolet 6700 FT-IR spectrometer in the region of $4000-400 \mathrm{~cm}^{-1}$. The spectra were recorded with a resolution of $4 \mathrm{~cm}^{-1}$ and 100 scans with a DTGS detector in KBr. The samples (approximately $10 \mathrm{mg}$ ) were finely ground and $5 \%$ diluted in $\mathrm{KBr}$, placed in a ceramic crucible in a DRIFTS (Nexus Smart Collector, Nicolet) chamber.

Before collecting the spectra, the samples were pre-treated ex situ as shown in Figure 3. First, they were heated in $\mathrm{N}_{2}$ flow at $400{ }^{\circ} \mathrm{C}$ for 45 minutes to remove surface contaminants. The adsorption of pyridine was carried out at $100{ }^{\circ} \mathrm{C}$ with a stream of $\mathrm{N}_{2}$ saturated at room temperature (RT). Then, pure $\mathrm{N}_{2}$ was again passed over the samples at $100{ }^{\circ} \mathrm{C}$ to be able to sweep the weakly adsorbed pyridine residues on samples and then cooled to RT to perform further analysis by IR.

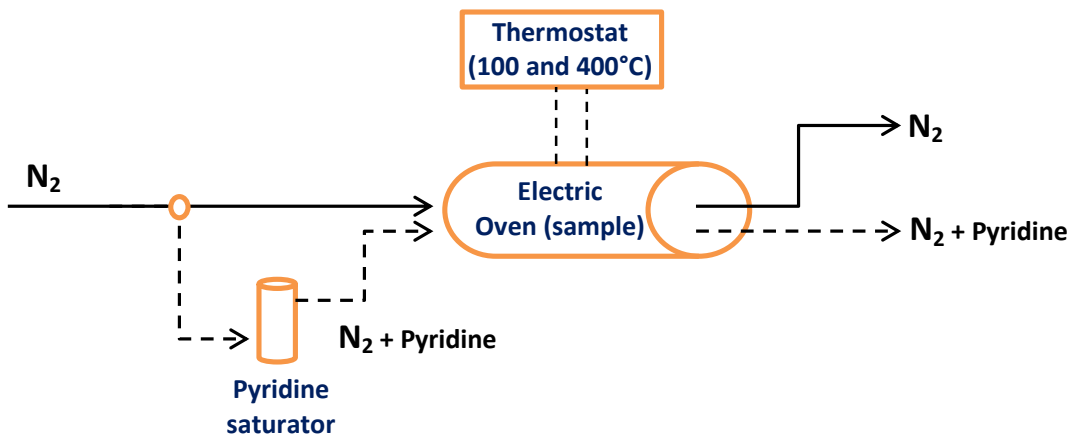

Figura 3: Schematic diagram of the system employed for the previous and post treatment on the pyridine adsorption of zeolites samples for the determination of acid sites by IR.

\section{Conclusions}

From all these studies, we can conclude that Mordenite, 13X and ZSM-5 zeolites are highly efficient and eco-friendly Lewis acid catalyst in the tricomponent and sequential reaction presented here for the diastereoselective synthesis of 1,4-thiazepan- 3-ones (4) and 4-thiazolidinones (5). Besides, these reactions were fast and with a very easy workup (just filtering the zeolite) that allows getting the synthetized products without further treatment for the CG-MS determination. In future works we will extend these studies to more substrates and zeolites, with the aim of separate the diastereomeric products and evaluate their biological activity. 


\section{References}

1. Dua, R.; Shrivastava, S.; Sonwane, S.K.; Srivastava, S.K. Advances in Biological Research, 2011, 5, 3, 120-144, DOI 10.4236/ojmc.2012.23011.

2. (a) Karnakar, K.; Narayana Murthy, S.; Ramesh, K.; Harsha, V. R. ; Nageswar Y. V. D.; Chandrakala, U.; Prabhavathi Dev, B. L. A.; Prasad, R. B. N. Tetrahedron Lett. 2012, 53, 27, 3497-3501, DOI: 10.1016/j.tetlet.2012.04.047. (b) Ajay Kumar, K.; Renuka, N.; Raghavendra, K.; Vasanth, Kumar, G.; Ranjitha, B. K. International Journal of Basic and Applied Chemical Sciences (IJBAS), 2015, 5, 1, 79-88, ISSN: 2277-2073.

3. (a) Tong, H. G.; Skidmore, D.; Maibak, H. I.; Skinner, W. A. Chem. Abst, 1979, 26, 728-731. (b) Verma, A.; Saraf, S. K. Eur. J. Med. Chem., 2008, 43, 897-905, DOI: 10.1016/j.ejmech.2007.07.017; (c) Yadav, L. D. S.; Vaish, A.; Sharma, S. J. Agric. Food Chem.,1994, 42, 811-815. ISSN: 0021-8561.(d) Rao, R. P. Curr. Sci., 1966, 35, 541. (e) Vigorita, M. G.; Ottana, R.; Monforte, F.; Maccari, R.; Trovato, A.; Monforte, M. T.; Taviano, M. F. Bioorg. Med. Chem. Lett., 2001, 11, 2791-2794, DOI: 10.1016/S0960-894X(01)00476-0. (g) Diurno, M. V.; Mazzoni, O.; Correale, G.; Monterrey, I. G.; Calignano, A.; Rana, G. L.; Bolognese, A. II Farmaco., 1999, 54, 579-583. DOI: 10.1016/S0014-827X(99)00064-6. (h) Sinhg, S. P.; Parmar, S. S.; Raman, K.; Stenberg, V. I. Chem. Rev., 1981, 81, 175-203. DOI: 0009-2665/81/0781-0175 (i) Kato, T.; Ozaki, T.; Tsuzuki, K.; Ohi N. Process Res. Dev., 2001, 5, 122-126. DOI: 10.1021/op000096h (j) Gududuru, V.; Hurh E.; Dalton T. J.; Miller D. D. J. Med. Chem., 2005, 48, 2584-2588. DOI: 10.1021/jm049208b (k) Bonde, C. G.; Gaikward, N. J. Bioorg. Med. Chem., 2004, 12, 2151-2161. DOI: 10.1016/j.bmc.2004.02.024 ; (l) Geissler, J. F.; Traxler, P.; Regenass, U.; Murray, B. J.; Roesel, J. L.; Meyer, T.; Mcglynn, E.; Storni, A.; Lydons, N. B. J. Biol. Chem., 1990, 265, 22255-22261. ISSN: 0021-9258; (m) Newcome, G. R.; Nayak, A. Heterocycl. Chem., 1979, 25, 83-112. ISSN: 1943-5193.

4. Ocampo, R. A.; Quiroga, A. A.; Koll, L. C; Fascio, M.; D’accorso, N. B. Síntesis y caracterización de 4-tiazolidinonas unidas a heterociclos nitrogenados y sustituidas por un carbohidrato adecuadamente funcionalizado. XX Simposio Nacional de Química Orgánica. Mar del Plata, Argentina; 11-14 november 2015; Editor: SAIQO; SO-176; ISSN: 2347-0267.

5. R. A. Ocampo, L. C. Koll, M. Fascio, S. D. Mandolesi, N. B. D'Accorso, in Proceedings of the $18^{\text {th }}$ Int. Electron. Conf. Synth. Org. Chem., 2014; Sciforum Electronic Conference Series, ISBN: 3-906980-24-3.

6. M. G. Montiel Scheider.; R. A. Ocampo, S. D. Mandolesi; L. C. Koll. Síntesis de ésteres borónicos y sus aplicaciones como catalizadores estereoselectivos. XX Simposio Nacional de Quimica Organica, Mar del Plata, Argentina; 11-14 november 2015; Editor: SAIQO; SO-142; ISSN: 2347-0267.

7. Ocampo, R. A.; Quiroga, A. A.; D'accorso, N. B. Estudio de la síntesis estereo y diasteroselectiva de una nueva 1,4-tiazepan-3-ona sustituida por un hidrato de carbono utilizando irradiación de microondas. XX Simposio Nacional de Química Orgánica. Potrero de los Funes, San Luis, Argentina; 8-11 november 2017; Editor: SAIQO; SO-129.

8. Shu-Jiang, T.; Xu-Dong, C.; Wen-Juan, H.; Xiao-Hong, Z.; Shu, Y.; Shan-Shan, W.; Zheng-Guo, H.; Feng, S. Org. Biomol. Chem. 2009, 7, 557-563, DOI: 10.1039/b815879g

9. Brunauer, S.; Emmet, P.H.; Tellet, E. Adsorption of Gases in Multimolecular Layers. J. Am. Chem. Soc. 1938,60, 2, , 309-319, DOI: 10.1021/ja01269a023

10. (a) Lercher, J.; Gründling, C.;Eder-Mirth, G. Catal. Today 1996, 27(3-4), 353-376, DOI: 10.1016/0920-5861(95)00248-0 (b) Parry, E. P. J. Catal. 1963, 2 (5), 371-379, DOI: 10.1016/0021-9517(63)90102-7 (c) Avila, A. J.; Tonetto, G. M.; Damiani, D. E. Catal. Com. 2011, 12, 362-367, DOI: 10.1016/j.catcom.2010.10.007.

11. Padró, C.L.; Rey, E.A.; González Peña, L.F.; Apesteguía C.R. Microporous and Mesoporous Materials 2011, 143, 236-242, DOI: 10.1016/j.micromeso.2011.03.005.

12. Figueiredo H.; Silva. B.; Quintelas, C.; Neves, I.C.; Tavares, T. Biosorption of $\mathrm{Cr}^{\mathrm{VI}}$ supported on mordenite zeolite. Proceedings of the 10th International Chemical and Biological Engineering Conference CHEMPOR 2008 Braga, Portugal, September 4-6, 2008. ISSN: 1369-703X.

13. Boveri, M.; Márquez-Álvarez, C.; Laborde M.A.; Sastre, E..Catal. Today 2006, 114, 217-225, DOI: 10.1016/j.cattod.2006.01.012.

14. (a) Yang, H.; Fairbridge, C.; Ring, Z.; Hawkins, R.; Hill, J. M. Studies in Surface Science and Catalysis 2002, 141, 543-551, DOI: 10.1016/S0167-2991(02)80588-2.

15. Bezerra, D.P.; da Silva, F.W.M.; de Moura, P.A.S.; Sousa, A.G.S.; Vieira, R.S. ; Rodriguez-Castellon, E.; Azevedo, D.C.S. Applied Surface Science 2014, 314, 314-321, DOI: 10.1016/j.apsusc.2014.06.164.. 
16. Rosenthal, D. J.; White, M. G.; Park, G. D. AIChE J. 1987, 33, 336-340, DOI: 10.1002/aic.690330226.

17. Patil, M. K.; Keller, M.; Reddy, B. M.; Pale, P.; Sommer, J. Eur. J. Org. Chem. 2008, 4440-4445. DOI: 10.1002/ejoc.200800359. 